DOI: https://doi.org/10.4796o/2303-7431.24.2020.180

UDK: 81'373.612.2:272-247

Izvorni znanstveni članak

Primljen 17. XI. 2020.

Prihvaćen 3. IV. 2021.

Frano Musić

Zagreb

frafrano@yahoo.com

\title{
METAFORE U EVANĐEOSKOME KODIRANJU: PRIMJER LUKINA EVANĐELJA
}

\section{Sažetak}

U radu se najprije nastojalo sažeto prikazati povijesni pregled najvažnijih teorijâ metafore koje se mogu pratiti od Aristotelova sustavnog proučavanja u dvjema zasebnim područjima, retorici i poetici, pa sve do novijih istraživanja u kognitivnoj lingvistici i semantici. Glavne postavke najvažnijih teoretičara metafore koje su iznesene poslužile su kao okvir u kojemu su se promotrili i raščlanili pojedinačni primjeri metaforâ u Lukinu Evanđelju. U analitičkome je dijelu izdvojeno i opisano nekoliko biblijskih pojmova (srce, kralj, kraljevstvo Božje, vjera i kuća) važnih za razumijevanje središnje evanđeoske poruke.

Ključne riječi: metafora; Lukino Evanđelje; kraljevstvo Božje; srce; vjera

\section{Uvod}

Kognitivno-semantički pristup metafori, s Lakoffom i Johnsonom kao predvodnicima, pružio je znatne i vrijedne uvide koji su primjenjivi na sve vrste tekstova, pa tako i na biblijske. Bît se metafore iz ove perspektive prepoznaje u razumijevanju i doživljavanju jedne pojmovne domene u smislu druge domene, izvorne i ciljne, na temelju niza 
podudarnosti ili preslikavanja između tih domena. Spomenuti autori ne promatraju metaforu kao figuru koja se odnosi na riječi i kao jezični ukras, nego naglašavaju da metafore predstavljaju neizbježan proces ljudske misli, promišljanja i doživljavanja, spontano i bez napora. Imajući sve to na umu, s pravom se može tvrditi da je moć metafore osobito prepoznatljiva u vjerskome diskursu. Metafore popunjavaju leksičke praznine i omogućavaju jasan govor o uzvišenim, duhovnim stvarnostima na temelju vidljive stvarnosti i svakodnevnoga ljudskog iskustva. Svojom izravnosti rasvjetljavaju teško objašnjive odnose stvarajući cijelu mrežu asocijacija i odnosa. Tragovi toga trebaju se prepoznati i u ovome radu, u kojemu će se nastojati pokazati da je metafora nezaobilazna u evanđeoskim tekstovima, osobito stoga što evanđeoska poruka po sebi nadilazi doslovno razumijevanje.

Primjeri metaforâ uzeti su iz Biblije u izdanju Kršćanske sadašnjosti, prijevod Novoga zavjeta dr. fra Ljudevita Rupčića.

\section{Metafora}

Širok je spektar pristupa i promatranja kojima se nastojalo opisati i odrediti bît metafore, koja je svojom višestrukosti i posebnosti ostala neprestanim izazovom filozofskim, lingvističkim i drugim znanstvenim područjima. Zbog raznolikosti uporabe čak se govori o sto dvadeset pet različitih definicija ove figure jer se „definicija korisna jednoj disciplini često pokazuje nezadovoljavajućom drugoj “ ${ }^{{ }_{1}}$. Općenito metafora je ( $\mu \varepsilon \tau \alpha-\phi \varepsilon \dot{\varepsilon} \omega$ - drugamo nositi, premjestiti, prenijeti, primijeniti na koga ili što) svako preneseno značenje, slikovito izražavanje, što se ponajprije povezuje s različitim pjesničkim umijećima. ${ }^{2}$

Janet Martin Soskice, Metaphor and Religious Language, Oxford University Press, New York, 1985. (ponovljeno izd. iz 2002. godine), str. 15.

2 Usp. Rikard Simeon, Enciklopedijski rječnik lingvističkih naziva, sv. I., Matica Hrvatska, Zagreb, 1969., str. 809. 


\subsection{Kratak pregled teorijskih pristupa metafori}

Pojmovno nas određenje metafore uvodi u prikaz najvažnijih proučavanja metafore, koja svoj početak nalaze u Aristotelovu supstitucijsko-poredbenome pristupu, potom u Richardsovoj i Blackovoj interakcijskoj teoriji, sve do semantičkih i kognitivnih pristupa. Dijakronijski pogled razvoja ovih teorijâ metafore zahvaća početno razumijevanje metafore kao pjesničkoga ukrasa i uveseljavanja, prekid s ukrasnom ulogom i uzdizanje metafore na višu razinu od riječi, do spoznajnoga sredstva i doživljaja svijeta u kognitivnoj lingvistici i semantici. Naime, s motrišta kognitivne lingvistike metafora je „oblik mišljenja s vlastitim epistemološkim funkcijama“ jer „empirijska istraživanja u kognitivnoj znanosti ukazuju na to da su mnogi vidovi svakodnevnog razmišljanja i jezika zapravo metaforički, tako da metaforu možemo shvatiti kao primarni oblik mišljenja“3.

\subsection{Aristotelova teorija metafore}

Aristotel o metafori govori u okviru retorike i poetike kao dvaju zasebnih područja. Retorika je za Grke predstavljala govorničku vještinu s ciljem uvjeravanja slušatelja u neke stavove i razmišljanja, umijeće rasprave, obrane, pohvale, pokude i osude. Nasuprot tomu, poetika ne ide za uvjeravanjem i nije govornička vještina, ona ništa ne dokazuje, nego je umjetnost pjesmotvorâ, i to ponajprije tragičara. Riječ je, dakle, o dvama različitim diskursima u kojima metafora ima važnu ulogu iako se ne vezuje ni za jedan od tih diskursa, nego samo za ime (óvo $\mu \alpha)$, kao prvi entitet koji ima značenje. ${ }^{4}$

U Poetici Aristotel ovako definira metaforu: „Metafora je prenošenje na neku stvar imena koje označava drugu stvar, prenošenje ili s roda na vrstu ili s vrste na rod ili s vrste na vrstu ili prema odnosu analogije" -

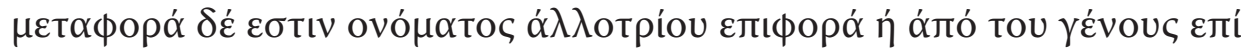

Zjena Čulić, Čovjek, metafora, spoznaja, Književni krug, Split, 2003., str. 11.

4 Aristotelova Poetika, preveo i izdao Martin Kuzmić, Tisak Kraljevske zemaljske tiskare,

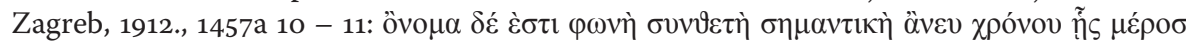

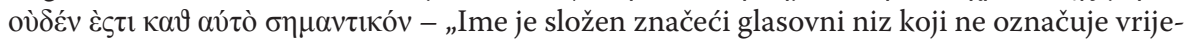
me, a čiji nijedan dio sam po sebi nema značenja." 


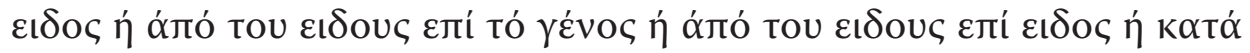

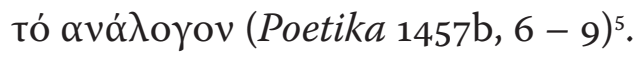

Tri su vrlo važna obilježja ove definicije. Prva je da se metafora ograničava na riječi. Metaforički se prijenos događa na razini riječi, a ne na razini rečenice ili diskursa. Nadalje, metafora nudi otklon u odnosu na doslovnu uporabu jezika, jer je prijenos imena na neku stvar kojoj zapravo ne pripada. Aristotel to ime naziva stranim i govori o svojevrsnoj posudbi toga imena.

Metafora se, po trećemu obilježju, temelji na analogiji, sličnostima koje omogućavaju da dođe do prijenosa. Aristotel govori da je najvažnije isticati se u metafori, biti metaforičan, što se ne može naučiti, nego je pokazatelj prirodne darovitosti koja se posebice očituje u uočavanju

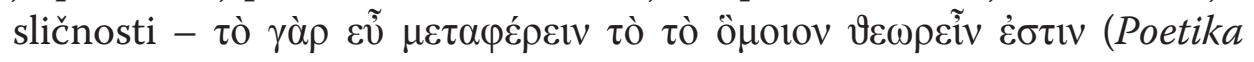
$1459 a, 7)^{6}$. U doslovnome prijevodu to bi značilo: „dobro metaforizirati znači dobro uočavati sličnosti“.

\subsection{Interakcijska teorija metafore}

Slijedilo je dugo razdoblje proučavanja i razrade Aristotelovih ideja o metafori mnogih teoretičara metafore. Jedan je od važnijih Ivor Armstrong Richards, koji oživljava proučavanje metafore. Ovaj autor proširuje okvir grčke retorike i metaforu ne povezuje sa semantikom rečenice, nego s novom definicijom retorike, kojoj je kao filozofskoj disciplini cilj ovladati temeljnim zakonima jezične uporabe. Naglasivši posebice jezičnu uporabu retorike, Richards je „smješta na izrazito verbalni plan razumijevanja i komunikacije; retorika je teorija diskursa, misli kao diskursa“7. Retorika je proučavanje „verbalnog razumijevanja“ i „lošeg razumijevanja riječi“" ${ }^{\text {, }}$, radi ovladavanja zakonima jezične uporabe.

Za Richardsa je diskurs nositelj značenja, a riječi nemaju nikakvo značenje. Da bi se dosegnuli viša razina i značenje, nezaobilazan je kontekst kao „ime za snop događaja koji se zajedno pojavljuju, a u taj snop

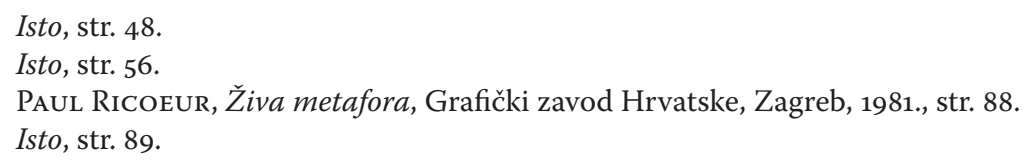


uključujemo isto tako i odgovarajuće uvjete kao i ono što možemo izolirati kao uzrok ili kao učinak“9. Iz toga nastaje „kontekstualni teorem značenja ${ }^{\text {"10 }}$, što je vrlo važno za razumijevanje kako metafora djeluje u jeziku: „Najjednostavnije rečeno, kada rabimo metaforu, imamo dvije misli o različitim stvarima koje djeluju zajedno, a oslanjaju se na jednu riječ ili izraz, čije je značenje rezultanta njihove interakcije (međudjelovanja). ${ }^{{ }_{11}}$ Važno je zapaziti da Richards polazi od zamisli da značenje rečenice ne proizlazi iz značenja riječi, nego značenje riječi potječe iz raščlambe rečenice i iz izoliranja jednoga od njezinih dijelova. Tako postavlja interpretacijsku teoriju na kojoj će utemeljiti interakcijsku teoriju. Za razliku od Aristotela, koji tvrdi da je za ovladavanje metaforom potrebna darovitost duha i da se ne može naučiti, Richards metaforu poimlje kao jezičnu djelatnost koja je „životno metaforička“ i koja djeluje u svakodnevnoj uporabi, u verbalnoj interakciji.

Osim navedenoga uvodi pojam „transakcije među kontekstima“ koji pobliže određuje odnosom između sadržaja i prijenosnika. ${ }^{12}$ Pojmom napetosti opisuje spomenuti odnos između sadržaja i prijenosnika, a koji je inkompatibilan.

Nastavak Aristotelovih, a osobito Richardsovih postavaka o metafori ponudio je Max Black predstavljajući dva različita pristupa opisu metafore: supstitucijski i poredbeni. „Supstitucijski pristup zastupa gledište kako se kod razumijevanja metafore metaforički termini zamjenjuju doslovnim terminima koji pristaju u isti kontekst. ${ }^{\text {“13 }}$ A poredbeni (komparativni) pristup „nagoviješta kako se metafora sastoji od predstavljanja neke latentne analogije ili sličnosti u obliku sažete ili eliptične figure, odnosno simile ${ }^{{ }_{14}}$. Ovim dvjema teorijama suprotstavlja interakcijsku teoriju, koja se nastavlja na Richardsova promišljanja o stvaranju

\footnotetext{
$9 \quad$ Isto, str. 90.

10 Ivor Armstrong Richards, The Philosophy of Rhetoric, Oxford University Press, [1936.], 1971., str. 40.

${ }_{11} \quad$ Isto, str. 24.

12 Richards pojmom sadržaja (tenor) označava prvu ideju, a pojmom prijenosnika (vehicle) ideju kojom se prva ideja razumijeva. Usp. isto, str. 96.

13 Z. Čulić, $n$. $d j$., str. 14.

14 Isto.
} 
metaforičkoga značenja koje potječe od interakcije dviju misli koje istodobno postoje.

Max Black poziva se na Richardsova promišljanja i na njegovu tvrdnju o uporabi metafore. Po njegovu mišljenju ovakav tip analize nadilazi glavne nedostatke supstitucijskoga i poredbenoga razumijevanja metafore, a istodobno pruža neke važne uvide u namjenu i ograničenja metafore. ${ }^{15}$ Supstitucijsko se razumijevanje metafore za ovoga autora odnosi na svako razumijevanje po kojemu se metaforički izraz rabi umjesto odgovarajućega doslovnog izraza, a poredbeno je razumijevanje metafore u predočavanju pretpostavljene sličnosti ili analogije. Interakcijskim se pak razumijevanjem metafore stvara novo značenje središnje, žarišne (fokalne) riječi ili izraza, koje ne odgovara njezinu doslovnom značenju. Proširenje značenja omogućava novi kontekst ili okvir, pri čemu je važna svijest o proširenome značenju. ${ }^{16}$

U svome djelu Models and Metaphors ${ }^{17}$ Black sažimlje najvažnije teze značenjske analize metafore. Metafora se, po njegovu mišljenju, uspostavlja na razini čitavoga iskaza „da bi objasnila promjenu značenja koja se usredotočuje u riječi ${ }^{\prime \prime 18}$. Postoji sustav asociranih općih mjesta pomoću kojega se metafora ostvaruje kao usporedba dvaju predmeta, i to interakcijom: „Interakcija je zapravo pretraživanje jednog sustava zajedničkih osobina pomoću drugog sustava kako bi se stvorila nova konceptualna organizacija nekog predmeta." ${ }^{\text {"19 }}$

Treba reći da bi u opsežnijemu dijakronijskom pregledu svakako bilo mjesta za J. R. Searleovu pragmatičku teoriju metafore, za strukturalistički pristup R. Jakobsona, kao predstavnika objektivističkih teorija, ali i za M. Reddyja i njegovu teoriju provodnika, kojom se najavljuje kognitivni pristup jeziku i metafori. Međutim, potrebe ovoga rada ne

${ }_{15}$ Usp. Metafora, figure i značenje: Zbornik teorijskih radova, izabrao i priredio LEON KoJEN, Beograd, 1986., str. 68.

16 Usp. isto, str. 69.

${ }_{17}$ Max Black, „Metaphor“, Models and Metaphors, Cornell University Press, Ithaca, New York, 1962., str. 25. - 47.

${ }_{18}$ Metafora, figure i značenje: Zbornik..., str. 96.

19 Isto. 
zahtijevaju iscrpan i zaokružen pregled svih teorija te je dovoljno još nešto reći o kognitivnome pristupu metafori.

\subsection{Kognitivna teorija metafore i konceptualna metafora}

Proučavanje se metafore, kako se moglo vidjeti, razvijalo u dvama različitim polazištima. Prvi se odnosio na jezik, pri čemu je metafora bila samo govorničko sredstvo, ukras u jeziku. S pojavom kognitivne lingvistike, osobito kognitivne sematnike, metafora postaje mentalnom strukturom i ima vrlo važnu ulogu u gradbi značenja i oblikovanju značenjskih struktura i misli. Metafora nije samo jezični fenomen nego predstavlja pojmovni i iskustveni proces struktura ljudskih ideja o svijetu. G. Lakoff i M. Johnson ${ }^{20}$ tvrde da je bît metafore najprije pojmovna, a tek potom jezična. Metafora zapravo odražava strukture mišljenja i osnovna pojmovna preslikavanja jer je pojmovni sustav po sebi metaforičan. Stoga se metafora ne može svoditi samo na jezičnu stvarnost. Metafora omogućava razumijevanje nekoga područja pomoću drugoga područja, jedne kognitivne domene pomoću druge na temelju pojmovne sličnosti ${ }^{21}$. Kognitivne se domene „nazivaju izvornom i ciljnom domenom, pri čemu je izvorna domena osnova ili pozadina za razumijevanje ciljne domene ${ }^{{ }_{22}}$. Izvorna domena, kao nešto poznato, konkretno i blisko, omogućava razumijevanje ciljne domene kao nečega nejasnoga i apstraktnoga, manje poznatoga, na temelju iskustva. ${ }^{23}$ Riječ je o temeljnoj misli na kojoj nastaje konceptualna teorija metafore. ${ }^{24}$ Važno je znati da metaforičnost nije u jezičnim izrazima, nego u metaforičkome

2o George Lakoff - Mark Johnson, Metaphors we live by, Chicago University Press, Chicago - London, 1980.

${ }^{21}$ Usp. George Lakoff - Mark Turner, More than cool reason: A field guide to poetic metaphors, Chicago University Press, Chicago, 1989., str. xi.

22 IDA Raffaelli, Značenje kroz vrijeme: Poglavlja iz dijakronijske semantike, Disput, Zagreb, 2009., str. 77 i 78.

${ }^{23}$ Usp. Zoltán Kövecses, Metaphor and Emotion: Language, Culture, and Body in Human Feeling, Cambridge University Press, Cambridge, 20oo., str. 4.

24 Usp. RAYMOND W. GIBBS, JR., „Taking metaphor out of our heads and putting it into the cultural world“, RAymond W. Gibbs, Jr. - Gerard J. Steen (ur.), Metaphor in cognitive linguistics, John Benjamins Publishing Company, Amsterdam - Philadelphia, 1999., str. 45. 
pojmu koji je „kao polazište i okvir iz kojega jezik 'pretače' metaforično značenje u razne 'jezične izraze ${ }^{\prime \varkappa_{25}}$.

Velike su zasluge ove dvojice začetnika kognitivne teorije metafore da su metaforu vratili u svakodnevnu uporabu, u jezik i misli, suprotno od retoričkoga poimanja i književne kritike gdje se promatrala kao ukras i sredstvo uvjeravanja. ${ }^{26}$ To je pokrenulo brojna proučavanja metafore u svakodnevnome jeziku, rekonstrukciji temeljnih pojmova metafore i opisu oblikovanja konceptualnih metafora načinom razmišljanja, doživljavanja i djelovanja.

Za potrebe analitičkoga dijela rada naglašavamo Lakoffovu i Johnsonovu shemu SPREMNIKA po kojoj se ljudi shvaćaju kao tjelesna bića „koja su odijeljena granicama od ostatka svijeta samom površinom svoje kože te doživljavaju ostatak svijeta kao nešto izvan njih samih“. „Svaki je čovjek spremnik s ograničenom površinom i orijentacijom unutra-vani. Ta se orijentacija projicira na druge fizičke predmete koji su omeđeni površinama. Na taj način i te predmete doživljavamo kao spremnike s unutrašnjim i vanjskim dijelom. “" ${ }^{27}$ Razlikuju se sheme TIJELO U SPREMNIKU, kao pokazatelj ograničenja i zatvorenosti (zatvor, zamka i zatvoreni prostor kao značenje gubitka slobode), i TIJELO KAO SPREMNIK različitih osjećaja i stanja.

\section{Metafore u Lukinu Evanđelju}

Olaf Jäkel u svojemu članku o kognitivnoj teoriji metafore primijenjenoj na vjerski diskurs nabraja poznate konvencionalne metafore kojima se Boga opojmljuje kao oca, pastira, zemljoposjednika, gospodara, kralja, sudca itd. dovodeći ih osobito u vezu s načelom jednosmjernosti i nužnosti. Po njemu većina ovih naziva za Boga ne dolazi iz izvornih

\footnotetext{
${ }_{25}$ Milena ŽıC FuCHS, „Konvencionalne i pjesničke metafore“, Filologija, Zagreb, br. 20 - 21, 1992. - 1993., str. 586.

26 Usp. Cornelia Müller, „What gestures reveal about the nature of metaphor", Metaphor and Gesture, John Benjamins Publishing Company, Amsterdam - Philadelpia, 2008., str. 220.

${ }_{27}$ Ž. Čulić, $n$. $d j$., str. 145.
} 
domena koje čine jasno označene predodžbene sheme. ${ }^{28}$ Zoltán Kövecses govori o simbolima koji se u Bibliji rabe za Boga i Isusa, pozivajući se pritom na Roberta C. Nevillea ${ }^{29}$, s tvrdnjom da se Boga iz kognitivno-lingvističke perspektive mora opojmiti metaforički pomoću manje apstraktnih entiteta..$^{30}$ Isti je autor oprimjerio ciljne domene iz vjerskoga područja kojima se prikazuje naš pogled na Boga, kao i odnos prema njemu, izdvojiviši posebice pojmove oca, pastira, kralja.$^{31}$ Opsežno izlaganje o važnosti četiriju konceptualnih metafora u Lukinu Evanđelju, koje svoj odraz nalaze u starozavjetnoj i židovskoj tradiciji, nudi Gregory R. Lanier služeći se konceptualnom teorijom metafore za promatranje kristoloških izričaja. ${ }^{32}$

Proučavanje metaforičnosti evanđeoskih tekstova nije zatvoren krug ili jednosmjeran put, nego nudi raznolike pristupe, ovisno o namjeri onoga u čijemu su središtu zanimanja. I ovaj je pristup pokušaj vlastitoga prinosa spomenutoj mnogostrukosti. U ovome ćemo se dijelu rada usmjeriti na pet primjera metaforâ iz Lukina Evanđelja tj. pet važnih biblijskih pojmova - srce, kralj, kraljevstvo Božje, vjera i kuća, s namjerom da se prikažu načini preslikavanja predodžbenih shema. To će omogućiti jasno razlikovanje između uporabe metafora u evanđeoskome tekstu od uobičajenih očitovanja u svakodnevnome jeziku.

28 Usp. Olaf JäKel, „Hypotheses revisited: The Cognitive Theory of Metaphor applied to Religious Texts", Metaphorik.de, 2002., str. 24.; <https://www. metaphorik.de./de/journal/o2/hypotheses-revisited-cognitive-theory-metaphor-applied-religious-texts.htm>, (21. V. 2019.).

29 Vidi Robert Cummings Neville, Symbols of Jesus: A Christology of Symbolic Engagement, Cambridge University Press, Cambridge, 2001.

3o Usp. Zoltán KövecSes, "The biblical story retold: A cognitive linguistics perspective“, Cognitive Linguistics: Convergence and Expansion, Mario Brdar- Stephan Th. Gries - Milena Žrc Fuchs (ur.) Human Cognitive Processing, sv. 32, John Benjamins Publishing Company, Amsterdam - Philadelphia, 2011., str. 329.

${ }_{31}$ Usp. Zoltán Kövecses, Metaphor: A practical Introduction, Oxford University Press, New York, 2010., str. 26.

32 Gregory R. Lanier, Old Testament Conceptual Metaphors and the Christology of Luke's Gospel, T\&T Clark, London, 2018. 


\subsection{Srce}

Pojam se srca različito očituje. Najprije, riječ je o personifikaciji. Srce predstavlja ljude koji su se udaljili od moralnih načela, stanovitih vrijednosti i ideala i kojima je potrebno obraćenje.

„...Tvoja će ti žena Elizabeta roditi sina komu ćeš nadjenuti ime Ivan. Imat ćeš radost $i$ veselje, $i$ mnoge će obradovati njegovo rođenje. Dakako, bit će velik pred Gospodinom. Sigurno neće piti ni vina ni opojna pića; napunit će se Duhom Svetim još u majčinoj utrobi; mnoge će sinove Izraelove vratiti Gospodinu, Bogu njihovu. On će ići pred njim s Ilijinim duhom $i$ snagom, da vrati srca otaca prema djeci, a nepokorne nazoru pravednika, te pripremi Gospodinu sklon narod“(Lk 1, 13-17).

U drugome se primjeru srce odnosi na osobu Boga Oca, kojega se osobina da je milosrdan i sućutan, da prašta pridaje srcu kao simbolu središta osobe.

„...A ti ćěs se, djetešce, prorok Previšnjega zvati,

jer ćeš ići pred Gospodinom da mu pripraviš putove,

da narodu njegovu pružiš spoznaju

spasenja, koje biva oproštenjem grijeha njegovih,

zahvaljujući milosrdnom srcu Boga našega, zbog koga će nas pohoditi

Sunce s visine..." (Lk 1, $76-78)$.

Personifikaciju nalazimo i u metafori da Bog poznaje farizejska srca. Poznavati nečije srce značilo bi poznavati osobu, ono najvažnije o njoj. Ponovno srce predstavlja središte osobe:

To su slušali lakomi farizeji i rugali mu se. Isus im reče: „Vi se pravite pravednima pred ljudima, ali Bog poznaje vaša srca. Jer što je kod ljudi uzvišeno, pred Bogom je gnusoba" (Lk 16, 14 - 15).

Zanimljiv je primjer u kojemu se srcu pridaju ljudske osobine. Zbog načina života mogu otvrdnuti srca, što je metafora za ljudsku bezosjećajnost, nemar, krutost, nebrigu: 
„Pazite sami na se da vam srca ne otvrdnu od razuzdanosti, pijanstva $i$ tjeskobnih briga za život, da vas ne uhvati iznenada onaj dan kao zamka, jer će doći na sve stanovnike cijele zemlje. Bdijte i molite svaki čas, da biste mogli umaći svemu onomu što se ima dogoditi i održati pred Sinom Čovječjim" (Lk 21, 34-36).

Najbrojniji su primjeri metafora koje se temelje na shemi TIJELA KAO SPREMNIKA u kojoj se srce prikazuje kao spremnik za misli, ideje, sjećanje, pamćenje, sumnje:

A Marija je pamtila sve te događaje i razmišljala o njima u srcu svome (Lk 2, 19).

Tada side s njima, dođe u Nazaret i bijaše im poslušan. Njegova majka sve je te događaje brižno čuvala u srcu (Lk 2, 51).

Tada ih Šimun blagoslovi i reče Mariji, majci njegovoj: „Gle! Ovaj je određen za propast i uskrsnuće mnogih u Izraelu, za znak kojemu će se protiviti - a tebi će samoj mač probosti dušu - da bi se otkrile namisli mnogih srdaca"(Lk 2, 34-35).

Kako narod bijaše u iščekivanju i kako se svi u srcu pitahu o Ivanu da nije on Mesija, Ivan svima izjavi... (Lk 3, 15).

Dobar čovjek, iz dobre riznice svoga srca, iznosi dobro, a zao čovjek, iz zle riznice, iznosi zlo, jer mu usta govore onim čega mu je prepuno srce (Lk 6, 45).

'Kraj puta', to su oni koji uistinu čuju riječ; zatim dođe đavao te je iščupa iz njihova srca da ne vjeruju i ne spase se $(\operatorname{Lk} 8,12)$.

A što 'na dobru zemlju', to su oni koji čuju riječ i čuvaju je u dobru i plemenitu srcu $i$ rode rod zbog ustrajnosti $(\operatorname{Lk} 8,15)$.

U njima se porodi misao: tko bi od njih bio najveći? Isus, poznajući misao njihova srca, prihvati rukom malo dijete i postavi ga pokraj sebe te im reče: „Tko primi radi mene ovo malo dijete, mene prima. A tko mene prima, prima onoga koji je mene poslao. Tko je najmanji medu vama svima, taj je najveći“ (Lk 9, 46 - 48).

Ali, ako taj sluga pomisli u svom srcu: 'Moj gospodar zadugo neće doći... (Lk 12, 45).

Dok su oni još o tom govorili, sam Isus stade među njih te reče: „Mir vama!" Oni, zbunjeni i puni straha, pomisliše da gledaju duha. A on im reče: „Zašto ste zbunjeni? Čemu se takve sumnje radaju u vašim srcima? Pogledajte moje ruke i moje noge: ja sam, ja glavom! Opipajte me $i$ 
ustanovite! Duh nema mesa ni kostiju kao što vidite da ja imam" (Lk 24, $36-39)$.

Metafora ljubavi prema Bogu i bližnjima iskazuje se pomoću srca koje označuje nepodijeljenost, potpuno predanje, bezuvjetnost, cjelovitost osobe koja voli:

Tada, najedanput, ustade neki učitelj Zakona te ga zapita, u nakani da ga kuša: „Učitelju, što moram činiti da baštinim život vječni?" „Što stoji - odgovori mu - pisano u Zakonu? Što tamo čitaš?" "Ljubi Gospodina Boga svoga' - odgovori - 'svim srcem svojim, svom dušom svojom, svom snagom svojom i svom pameću svojom' a 'svoga bližnjega kao samoga sebe!" (Lk 10, $25-27)$.

Nešto slično je i u sljedećemu primjeru, u kojemu srce predstavlja opredjeljenje, pristajanje uz neke vrijednosti:

„Gdje je vaše blago, tu će biti i vaše srce" (Lk 12, 34).

Može se zapaziti i snažna metafora kojom se srcu pridaje svojstvo gorenja, čime se iskazuje oduševljenost, radost, prevelik zanos - srce gorjelo u nama. Riječ gorjelo ovdje je posve strana, kao da je „pala s neba“ i narušava odnose među jezičnim jedinicama i njihovim semantičkim poljima, ali samo ako se promatra doslovno. Metafora koja počiva na ovoj riječi zapravo je topos stanovita obrata značenja, ona na temelju staroga značenja producira novo značenje.

Njima se otvoriše oči i prepoznadoše ga... Ali njega nestade ispred njihovih očiju! Oni jedan drugomu rekoše: „Zar nije srce gorjelo u nama dok nam je putem govorio i tumačio Pisma!" (Lk 24, 31 - 32). 


\subsection{Kralj}

Pojam kralja nije zanimljiv zato što utjelovljuje stanovitu zemaljsku vlast, nego što se u Evanđelju govori o Isusu kao kralju. ${ }^{33}$ Riječ je o dvjema posve različitim i nespojivim kategorijama. Odabrani će primjeri pomoći da ta razlika bude očita.

Prvi primjer u kojemu se pojavljuje pojam kralja govori o konkretnoj osobi koja je na čelu židovskoga naroda, po kojoj se računalo vrijeme i koji bi se navodio u zapisivanju svih važnijih događaja:

U vrijeme Heroda, kralja judejskog, bio neki svećenik iz razreda Abijina, imenom Zaharija (Lk 1, 5).

Utjelovljenje vlasti i moći u osobi kralja nalazimo i u sljedećim primjerima:

Zatim se okrene te im reče napose: „Blago očima koje vide što vi vidite! Kažem vam da su mnogi proroci $i$ kraljevi htjeli vidjeti što vi vidite, ali ne vidješe; čuti što vi čujete, ali ne čuše" (Lk 10, 23 - 24).

„Ili, koji kralj, kad se sprema da zarati protiv drugoga kralja, najprije neće sjesti $i$ ispitati je li kadar oduprijeti se sa deset tisuća ljudi onomu koji ide na nj sa dvadeset tisuća? Ako ne može, šalje svoje poslanike dokje onaj još daleko, i moli za uvjete mira. Tako, dakle, tko se god između vas ne odreče svega svoga imanja, ne može biti moj učenik" (Lk 14, 31 - 33).

Zatim im reče: „Dići će se narod protiv naroda i kraljevstvo protiv kraljevstva. Bit će velikih potresa zemlje, a u raznim mjestima bit će kuge $i$ gladi. Bit će strahovitih pojava i na nebu velikih znakova. Ali prije toga svega stavit će ruke na vas te vas progoniti; predavat će vas u sinagoge $i$ tamnice; vodit će vas pred kraljeve i upravitelje zbog moga imena" (Lk 21, $10-12)$.

Nastade prepirka među njima o tome tko bi od njih bio najveći. Isus im reče: „Kraljevi narodâ gospodare nad njima, $i$ oni koji vrše vlast nad

${ }_{33}$ Metafora se kralja prepoznaje kao jedna od nezaobilaznih metafora za Boga, čak se po mišljenju mnogih autora može rabiti kao model koji osvjetljava naše razumijevanje Boga. Usp. J. M. Soskice, $n$. dj., str. 112; Sallie McFague, Metaphorical theology: Models of God in religious language, Fortress Press, Philadelphia, 1982., str. 141 i 142; VINCENT BRÜMMER, The model of love: A study in philosophical theology, Cambridge University Press, Cambridge, 1993., str. 26; JAN MUIS, „God our king“, HTS Theological Studies, god. LXIV. (2008.) br. 1., str. 270 . 
njima hoće da se zovu dobrotvori. A vi ne tako! Naprotiv, tko je najveći među vama, neka bude kao najmanji, a starješina kao poslužnik"(Lk 22, $24-26)$.

Ovomu se suprotstavlja pojam kralja koji se vezuje za Isusa. O sebi Isus ne govori kao o osobi koja je došla preuzeti vlast, za što su ga optuživali. Isus je poslan za spasenje, Mesija, kralj, ali ne židovski kralj koji će ih osloboditi ispod rimske vlasti. Podrugljivo Pilatovo pitanje otkriva kako ne razumije ono o čemu je Isus govorio, da njegovo kraljevstvo nije od ovoga svijeta.

Tada se svi digoše i odvedoše ga k Pilatu te ga počeše optuživati: „Ustanovili smo da ovaj buni narod i zabranjuje davati porez caru, a o sebi tvrdi da je Mesija, kralj". Pilat ga zapita: „Jesi li ti židovski kralj?" „Ti, kažeš", odgovori $m u(\operatorname{Lk} 23,2-3)$.

Istu poteškoću s naravi Isusova poslanja i kraljevstva o kojemu govori otkrivaju i vojnici koji ga izruguju dok je raspet na križu. Natpis ponad njegove glave da je kralj židovski, napisan na trima jezicima: grčkome, latinskome i aramejskome metafora je za kralja čitavoga svijeta, što će kasnije Crkva slaviti kao posebnu svetkovinu Krista Kralja svega stvorenja. Tri jezika na kojima je napisano da je Isus kralj židovski metafora su za čitavi svijet, tri civilizacije i kulture koje tvore jednu cjelinu.

I vojnici mu se izrugivali. Primicali se $k$ njemu, pružali mu ocat i govorili: „Ako si zaista kralj židovski, spasi sam sebe!" Nad njim stajaše i natpis

- na grčkom, latinskom i židovskom jeziku: „Ovo je kralj židovski“ (Lk $23,36-38)$.

\subsection{Kraljevstvo Božje}

U prijašnjemu je dijelu bilo govora o Božjemu kraljevstvu. Treba reći kako je središte Isusove poruke govor o blizini kraljevstva Božjega. ${ }^{34}$

34 Govor o kraljevstvu Božjemu, kao i središnji izraz „kraljevstvo Božje“ koji Isus odabire u svojemu navještaju, podrazumijeva shvaćanje Boga kao kralja. Eshatološka narav kraljevstva Božjega također pretpostavlja da njegovo ostvarenje ovisi o Božjemu kraljevanju. Usp. 
Ono zapravo počinje s njegovim dolaskom. Sve što Isus govori i čini posve je u službi kraljevstva Božjega koje naviješta pozivajući na obraćenje. Primjeri koji su izdvojeni pokazuju različite načine govora o kraljevstvu Božjemu. Ta različitost ide od činjenice da je već nastupilo, da ga treba navješćivati, da je blizu, da dolazi ili je već došlo, da ga treba tražiti...

On upravi pogled na svoje učenike te reče: „Blago vama, siromasi, jer je vaše kraljevstvo Božje!" (Lk 6, 20).

Jednom pozva k sebi Dvanaestoricu $i$ dade im moć $i$ vlast nad svim zlim duhovima i da liječe bolesne. Zatim ih posla da navješćuju kraljevstvo Božje i da ozdravljaju bolesnike (Lk 9, 1-2).

„Tko se postidi mene i mojih riječi, toga će se i Sin Čovječji postidjeti kad dođe u slavi svojoj i slavi Očevoj i svetih andela. - Uistinu, velim vam, ima nekih ovdje nazočnih koji sigurno neće umrijeti dok ne vide kraljevstvo Božje" (Lk 9, 26 - 27).

A drugomu reče: „Slijedi me!“ Ovaj odvrati: „Dopusti mi, Gospodine, da najprije odem i oca ukopam." „Pusti mrtve - reče mu Isus - nek ukopavaju svoje mrtvace. A ti hajde i navješćuj kraljevstvo Božje!" Zatim će mu neki drugi: „Ja ću te slijediti, Gospodine, ali mi najprije dopusti da se oprostim sa svojim ukućanima!“" Isus mu odvrati: „Nitko tko stavi ruku svoju na plug te se obazire natrag nije prikladan za kraljevstvo Božje" (Lk 9, 59 - 62).

„U koji god grad udete te vas prime, jedite što stave pred vas! Ozdravljajte bolesnike u njemu i narodu kažite: 'Približilo vam se kraljevstvo Božje!' $U$ koji god grad udete $i$ ne prime vas, izidite na njegove ulice i recite: 'Čak i prah vašega grada, što nam se uhvatio za noge, otresamo sa sebe i ostavljamo vama. Ali ovo znajte: blizu je kraljevstvo Božje.' Kažem vam da će Sodomi biti lakše u onaj Dan nego tomu gradu“ (Lk 10, 8 - 12).

Ako li ja Božjim prstom izgonim zle duhove, znači da je došlo k vama kraljevstvo Božje (Lk 11, 20).

Zato ne tražite što ćete pojesti ili popiti; ne uznemirujte se! - to sve traže pogani ovoga svijeta - jer vaš Otac zna da vam je to potrebno! Već tražite

J. Muis, $n$. dj., str. 274.; Wilfried HärLE, „Die Basileia-Verkündigung Jesu als implizite Gotteslehre“, Wilfried HÄrle - Reiner Preul, Reich Gottes, Elwert, Marburg, 1999., str. 17.; Andreas Lindemann, „Herrschaft Gottes/Reich Gottes IV: Neues Testament und spätantikes Judentum“, TRE, god. XV., 1986., str. 206. Za K. Bartha kraljevstvo nije središnji teološki pojam, nego jedan od ključnih modela koji se treba nadopuniti drugim pojmovima. Usp. Karl Barth, Die Kirchliche Dogmatik, I/2, Teologischer Verlag Zürich, Zürich, 1937., str. 976 i 980. 
njegovo Kraljevstvo, a to će vam se nadodati! Ne boj se, stado malo, jer je odlučio vaš Otac da vam dadne Kraljevstvo (Lk 12, 29 - 32).

„Do Ivana sežu Zakon i Proroci. Otada se navješćuje Radosna vijest o kraljevstvu Božjem. I svatko u nj navaljuje“(Lk 16, 16).

Farizeji ga upitaše: „Kad će doći kraljevstvo Božje?" On im odgovori: „Kraljevstvo Božje ne dolazi tako da se to može vidjeti; niti će se moći kazati: 'Evo ga ovdje' ili 'eno ga ondje,' jer kraljevstvo je Božje medu vama" (Lk 17, 20 - 21).

Dok su to slušali, nadoda još usporedbu zato što su držali da će se odmah pojaviti kraljevstvo Božje jer Isus bijaše blizu Jeruzalema (Lk 19, 11).

„Pojavit će se znaci na suncu, mjesecu i zvijezdama. Na zemlji će narodi biti u tjeskobi i neizvjesnosti zbog huke morskih valova. Ljudi će umirati od straha u očekivanju onoga što zadesiti svijet, jer 'zviježđa nebeska će se uzdrmati. Tada će vidjeti 'Sina Čovječjega gdje dolazi na oblaku's velikom moći i slavom. - Kada to počne bivati, uspravite se i podignite glave, jer je blizu vaše oslobođenje." Zatim im reče usporedbu: „Pogledajte smokvu i sva ostala stabla! Kad ih vidite da već pupe, znate sami od sebe da je blizu ljeto. Tako $i$ vi, kad vidite da to biva, znajte da je blizu kraljevstvo Božje! Zaista, kažem vam, ovaj naraštaj sigurno neće proći dok se to sve ne dogodi. Nebo će i zemlja proći, ali riječi moje sigurno neće proći“ (Lk 21, 25-33).

Isus ga pogleda te reče: „Kako mučno bogataši ulaze u kraljevstvo Božje! Lakše je devi kroz iglene ušice proći nego bogatašu ući u kraljevstvo Božje" (Lk 18, 24-25).

Kada dođe vrijeme, Isus sjede za stol s apostolima pa im reče: „Vruće sam želio da blagujem s vama ovu pashalnu večeru prije svoje muke, jer je, kažem vam, sigurno više neću blagovati dok se ne ispuni u kraljevstvu Božjemu." Tada uze kalež, zahvali i reče: „Uzmite ga i podijelite ga među sobom, jer od sada sigurno više neću piti, kažem vam, od trsova roda dok ne dođe kraljevstvo Božje!" (Lk 22, 14 - 18).

Pa nadoda: Isuse, sjeti me se kada dođeš u svoje kraljevstvo! (Lk 23, 42).

Uto neki čovjek imenom Josip, vijećnik, rodom iz judejskoga grada Arimateje, dobar i pravedan čovjek - on ne bijaše odobrio odluke i djela drugih - koji je očekivao kraljevstvo Božje, dođe k Pilatu i zatraži tijelo Isusovo (Lk 23, $50-52)$.

Osim govora o blizini i dolasku kraljevstva Božjega Isus govori o onima koji zaslužuju kraljevstvo Božje ili koji će teško u nj dospjeti: 
Neki su mu donosili i vrlo malu djecu da ih se dotakne. Kad to vidješe učenici, počeše ih riječima zaustavljati. Isus dozva k sebi dječicu te reče: „Pustite dječicu da dođu k meni; nemojte im priječiti, jer takvima pripada kraljevstvo Božje! Zaista, kažem vam, tko ne primi kraljevstvo Božje kao malo dijete, taj sigurno neće ući u nj" (Lk 18, 15 - 17).

Navedeni primjeri svjedoče o različitome leksikaliziranju metaforičkoga pojma kraljevstva Božjega. Bez teološkoga tumačenje teško ga je jezično odrediti. Ipak se jezično mogu prepoznati neke od kategorija u kojima se ono predstavlja:

- osoba koja dolazi, približava se ili će doći

- događaj koji se zbio ili će se zbiti

- stanje koje je nastupilo ili tek treba nastupiti

- mjesto ili prostor u koji treba ući

- doživljaj ili osjećaj.

\subsection{Vjera}

Oprimjerene metafore i govor o kraljevstvu Božjemu najbolji su uvod u govor o pojmu vjere. Isusov, naime, navještaj i govor o kraljevstvu Božjemu mogu se razumjeti i prihvaćati samo s vjerom. Pritom važnu ulogu imaju i njegova čudesna djela koja su ljudima pripomoć da vjeruju $\mathrm{u}$ istinitost Isusova poslanja. Isus je liječio, ozdravljao bolesne, istjerivao zloduhe, ali je zauzvrat samo tražio vjeru. Tako se vjera u nekim od primjera orječotvoruje kao nešto što ozdravlja, spašava pa i uskrisuje mrtve:

A on reče ženi: „Tvoja te vjera spasila. Hajde u miru!“ $(\mathrm{Lk} 7,50)$.

A Isus joj reče: „Kćeri, tvoja te vjera ozdravila, hajde u miru!" (Lk 8, 48).

Dok je on još govorio, dođe netko od ukućana predstojnika sinagoge te ovomu reče: „Kćerka ti umrije. Ne muči više Učitelja!“ Kad je to Isus čuo, reče mu: „Ne boj se! Samo vjeruj! Ozdravit će!“(Lk 8, 49 - 50).

I reče mu: „Ustani i hajde, tvoja te vjera spasila!“ $(\operatorname{Lk} 17,19)$. 
Kad mu se približi, upita ga: „Što hoćeš da ti učinim?“" Gospodine - odgovori - da progledam!“ „Progledaj - reče mu Isus - vjera te tvoja spasila“ (Lk 18, 40-42).

Vjera se predstavlja i kao nešto što se može vidjeti, izmjeriti, usporediti:

A on, vidjevši vjeru njihovu, reče: „Čovječe, oprošteni su ti grijesi“ (Lk 5 , 20).

Kad to ču Isus, zadivi mu se te se okrene mnoštvu koje ga je slijedilo, i reče: „Kažem vam, tolike vjere ne nađoh ni u Izraelu“ (Lk 7, 9).

Posebno je zanimljiva metafora u kojoj se vjera uspoređuje s malim gorušičinim zrnom. Time se naznačuje nedostatak vjere:

Apostoli zamoliše Gospodina: „Daj nam više vjere!“ Gospodin odvrati: „Ako zbilja imate vjeru koliko gorušičino zrno, rekli biste ovomu dudu: 'Iščupaj se s korijenom i presadi se u more!' i poslušao bi vas" (Lk 17, 5 - 6).

O pomanjkanju vjere govori i primjer kada su učenici bili s Isusom u lađici na jezeru kada je zapuhao snažan vjetar te su se preplašili:

A njima reče: "Gdje vam je vjera“ (Lk 8, 25).

Još je jedan primjer personifikacije u kojoj se vjeri pridaju ljudske osobine:

„Šimune, Šimune, pazi, sotona je dobio dopuštenje da vas može rešetati kao pšenicu, ali ja sam molio za te da tvoja vjera ne malakše. Tako i ti, kad se jedanput vratiš k meni, učvrsti svoju braću!" (Lk 22, 31 - 32).

\subsection{Kuća}

Prvi primjer u kojemu nalazimo pojam kuće odnosi se na Isusov boravak u hramu među učiteljima, gdje su ga Marija i Josip nakon tri dana traženja pronašli. Metaforički se skup odnosi na opredmećivanje, konkretiziranje, apstraktnih entiteta po kojemu se Božja kuća predstavlja hramom: 
Kad ga opaze, veoma se začude te mu majka rekne: „Dijete moje, zašto nam to učini! Gle! Otac tvoj i ja s bolom smo te tražili!" „Pa zašto ste me tražili? - odgovori im. - Zar niste znali da ja moram biti u kući Oca svoga?"(Lk 2, 48 - 49).

Slično je i s Isusovim govorom u prispodobi o gospodaru koji priređuje gozbu i poziva uzvanike. Time se metaforizira Božja ponuda, poziv na spasenje. Kuća je simbol zajedništva:

„Gospodar reče sluzi: 'Izađi na putove i među ograde $i$ natjeraj svijet da dođe da mi se napuni kuća!' Kažem vam da ni jedan od onih koji bijahu pozvani neće okusiti moje večere" (Lk 14, 23 - 24).

Nekoliko je primjera personifikacije u kojima se kuća shvaća u odnosu na ljude i njihovo ponašanje, pa joj se naviješta mir, došlo joj je spasenje i sl.:

„Zašto me zovete: 'Gospodine, Gospodine!' a ne vršite što vam kažem? Pokazat ću vam komu je sličan svaki onaj koji dođe kmeni, sluša moje riječi $i$ vrši ih. Sličan je graditelju kuće koji iskopa duboko te postavi temelj na litici. Nastane poplava, potok nahrupi na tu kuću, ali je ne može pokrenuti, jer je dobro sagradena. A onaj koji ču, a ne izvrši, sličan je čovjeku koji sagradi kuću na zemlji bez temelja. Navali na nju potok te se ona smjesta sruši, i velika bijaše ruševina te kuće" (Lk 6, 46 - 49).

„U koju god kuću udete, najprije recite: 'Mir kući ovoj!' Bude li tu tko dostojan mira, sići će na nj vaš mir; ne bude li nikoga, vratit će se k vama. U toj kući ostanite, jedući i pijući što oni imaju, jer radnik zaslužuje svoju plaću. Ne prelazite iz kuće u kuću“ (Lk 10, 5-7).

Kad Isus dođe na to mjesto, pogleda gore te mu reče: „Zakeju, sidi brzo, treba da se danas zadržim u tvojoj kući." On side brzo te ga s veseljem primi u goste. Svi koji to vidješe počeše mrmljati i govoriti: „Svratio se u kuću jednog grešnika!“ Zakej stade te reče Gospodinu: „Evo, polovicu svog imanja, Gospodine, dat ću siromasima. I ako sam koga u čemu prevario, vratit ću četverostruko." Reče mu nato Isus: „Danas je došlo spasenje ovoj kući, jer je i on Abrahamov sin. Da, Sin Čovječji došao je da traži i spasi što je izgubljeno" (Lk 19, 5-10).

„Jeruzaleme, Jeruzaleme, što ubijaš proroke i kamenuješ one koji su ti poslani! Koliko puta htjedoh skupiti djecu tvoju kao što kvočka skuplja piliće pod krila, ali vi ne htjedoste! Evo, vaša će kuća biti ostavljena vama! 
Kažem vam, sigurno me više nećete vidjeti dok ne dođe čas da reknete: Blagoslovljen koji dolazi u ime Gospodnje!" (Lk 13, 34 - 35).

\section{Zaključak}

Na temelju teorijskoga dijela o metaforama, osobito naslonjeni na kognitivnu teoriju metafore, $u$ analitičkome je dijelu izdvojeno pet biblijskih pojmova - srce, kralj, kraljevstvo Božje, vjera i kuća. Pomoću njih nastojala se prikazati metaforičnost evanđeoskoga teksta u pojedinačnim primjerima. Na početku je naglašeno kako je riječ o vrlo važnim, pa i središnjim, evanđeoskim pojmovima za razumijevanje Isusove temeljne poruke. Isusova poruka ide od navještaja kraljevstva Božjega koje s njim počinje. On je, dakle, Kralj, koji istodobno naviješta i donosi kraljevstvo Božje. Taj bi navještaj oni koji slušaju trebali prihvatiti, a prihvaća se srcem kao središtem bića, nutrinom, a ne vanjskim pristajanjem. Zato je potrebna vjera koja je uvjet za spasenje, za ulazak u kuću Očevu.

Primjeri pomno odabranih pojmova odražavaju jasnu razliku između njihova evanđeoskog poimanja u odnosu na svakodnevnu uporabu.

\section{Izvori i literatura}

- Aristotel, O pjesničkom umijeću, preveo i priredio Dukat, Zdeslav, Školska knjiga, Zagreb, 2005.

- Aristotelova poetika, izdao i preveo Kuzmić, Martin, Tisak Kraljevske zemaljske tiskare, Zagreb, 1912.

- Barth, Karl, Die Kirchliche Dogmatik, I/2, Teologischer Verlag Zürich, Zürich, 1937.

- Black, Max, Models and Metaphors, Cornell University Press, New York, 1962.

- Brümmer, Vincent, The model of love: A study in philosophical theology, Cambridge University Press, Cambridge, 1993. 
- Čulić, ZJenA, Čovjek, metafora, spoznaja, Književni krug, Split, 2003.

- GibBs, Raymond W., „Taking metaphor out of our heads and putting it into the cultural world“, GibBs, Raymond W. - Steen, GERARD W. (ur.), Metaphor in cognitive linguistics, Amsterdam/ Philadelphia: John Benjamins Publishing Company, 1999.

- Härle, Wilfried, „Die Basilea-Verkündigung Jesu als implizite Gotteslehre“, HÄrle, Wilfried - Preul, Reiner, Reich Gottes, Elwert, Marburg, 1999.

- JÄKEL, OlAF, «Hypotheses revisited: The Cognitive Theory of Metaphor applied to Religious Texts», Metaphorik.de, 2002., str. 24., <https://www. metaphorik.de./de/journal/o2/hypotheses-revisited-cognitive-theory-metaphor-applied-religious-texts.html>, (21. V. 2019.)

- Kojen, Leon (ur.), Metafora, figure i značenje: Zbornik teorijskih radova, Beograd, 1986.

- Kövecses, Zoltán, Metaphor and Emotion: Language, Culture, and Body in Human Feeling, Cambridge University Press, Cambridge, 2000 .

- Kövecses, Zoltán, Metaphor: A practical Introduction, Oxford University Press, New York, 2010.

- Lakoff, George - Johnson, Mark, Metaphors we live by, Chicago University Press, Chicago/London, 1980.

- Lakoff, George - Turner, Mark, More than cool reason: A field guide to poetic metaphors, Chicago University Press, Chicago, 1989.

- Lanier, Gregory R., Old Testament Conceptual Metaphors and the Christology of Luke's Gospel, T\&T Clark, London, 2018.

- Lindemann, Andreas, „Herrschaft Gottes/Reich Gottes IV: Neues Testament and spätantikes Judentum“, TRE, god. XV., 1986.

- Mcfague, Sallie, Metaphorical theology: Models of God in religious language, Fortress Press, Philadelphia, 1982. 
- MuIS, JAN, „God our king“, HTS Theological Studies, god. LXIV. (2008.) br. 1., str.

- Müller, Cornelia, Metaphor and Gesture, John Benjamins Publishing Company, Amsterdam - Philadelpia, 2008.

- Neville, Robert Cummings, Symbols of Jesus: A Christology of Symbolic Engagement, Cambridge University Press, Cambridge, 2001.

- Raffaelli, IdA, Značenje kroz vrijeme: Poglavlja iz dijakronijske semantike, Disput, Zagreb, 2009.

- Richards, Ivor Armstrong, The Philosophy of Rhetoric, Oxford University Press, [1936.], 1971.

- Ricoeur, Paul, Živa metafora, Grafički zavod Hrvatske, Zagreb, 1981.

- RupČIĆ, LJudevit, prijevod Novoga zavjeta, Biblija (Stari i Novi zavjet), Kršćanska sadašnjost, Zagreb, 1993.

- Rupčıć, Ljudevit, Novi zavjet i Psalmi, Hrvatsko biblijsko društvo - Naša ognjišta, Zagreb - Tomislavgrad, 2008.

- Simeon, Rikard, Enciklopedijski rječnik lingvističkih naziva (II), Matica Hrvatska, Zagreb, 1969.

- Soskice, Janet Martin, Metaphor and Religious Language, Oxford University Press, New York, 1985.

- ŽI IC Fuchs, Milena, „Konvencionalne i pjesničke metafore“, Filologija, Zagreb, br. 20. - 21., 1992. - 1993. 
Original scientific article

Received on November 17, 2020

Accepted on April 3, 2021

Frano Musić

\section{METAPHOR IN THE GOSPEL CODING: CASE STUDY THE GOSPEL OF LUKE}

\section{Abstract}

The paper seeks first to give a summarized historical overview of the most significant metaphor theories that can be followed from Aristotle's systematic studying in two separate areas, rhetoric and poetics, to contemporary research in cognitive linguistics and semantics. The paper describes the main tenets of the most important metaphor theorists which should serve as the framework in which the work on corpus is conducted, analysis of individual examples of metaphors in the Gospel of Luke. At the same time, we would like to emphasize that that is not the only, exclusive model of the analysis, but it contains a lot of its own contribution on the basis of the previous knowledge on metaphor. The reason for such approach can be found in the specific nature of the Biblical text, which is as a whole or in individual parts inherently metaphoric. The mentioned claims can be confirmed in the examples of metaphors from the Gospel of Luke, metaphor examples that put into words Biblical terms important for understanding the central Gospel message. The metaphor examples are taken from the Bible published by Kršćanska sadašnjost, translation of the New Testament by Friar Ljudevit Rupčić, PhD.

Keywords: metaphor; interaction theory of metaphor; cognitive theory of metaphor; conceptual metaphor, Gospel of Luke; heart; Kingdom of God; king; religion; house 